\title{
ARTICLES
}

DOI: $10.17803 / 2313-5395 \cdot 2021.2 .16 .314-330$

\section{Digital Services Taxes: The International Experience and Relevance for the Russian Federation}

\author{
Karina A. Ponomareva \\ Dostoevsky Omsk State University, Omsk, Russia
}

\begin{abstract}
The article deals with the problems arising in connection with the taxation of the digital economy, using the example of the proposals of the OECD and the EU on the introduction of a tax on digital services, as well as unilateral measures of national states in the area of taxation of the digital economy (on the example of the French digital tax). The main question for the study is whether unilateral measures imposing taxes on digital services represent a suitable solution to the tax problems that arise in connection with digitalization. Based on the legal analysis of both the EU Law provisions and domestic legal reality the author substantiates conclusions as applied to the Russian Federation

Keywords: tax law, digital economy, profit taxation, digital services tax, OECD, European Union, BEPS Action Plan, tax administration
\end{abstract}

Acknowledgements: The reported study was funded by Russian Foundation of Basic Research (RFBR), project number 20-11-00292 "Legal support of national tax security in conditions of international economic integration".

Cite as: Ponomareva, K.A., (2021). Digital services taxes: the international experience and relevance for the Russian Federation. Kutafin Law Review, 8(2), pp. 314-330, doi: 10.17803/23135395.2021.2.16.314-330 (In Eng.). 


\section{Contents}

I. Introduction. . . . . . . . . . . . . . . . . . . . . . 315

II. The OECD Concepts of Taxation in the Era of Digital Economy. . 317

III. Proposals of the European Commission in the Area of Direct Taxation............................. 318

IV. The EU DST Concept ......................... 319

V. Unilateral Measures to Introduce DST . .............. 321

V.1. General Characteristics of the French Digital Services Tax . . 322

V.2. Comparison of the French DST and the European

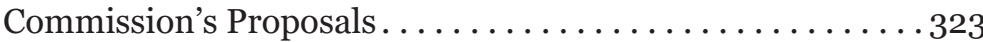

VI. DST and Double Taxation Issues . . . . . . . . . . . . . 324

VII. Relevance of the French Experience for Russia........... . 325

VIII. Conclusion . . . . . . . . . . . . . . . . . . . . . . . . 328

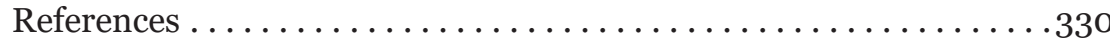

\section{Introduction}

The main characteristic of the digital economy is the reduction of the need for a physical presence in the markets. Value is created through user interaction and is concentrated in intangible assets that are easily transferred to tax havens in order to minimize taxable profits. Meanwhile, corporate tax systems are still based on the economic reality of the 1920s, when the current tax systems based on territorial and resident principles were created. As a result, there is a discrepancy between the places of profit creation and taxation. The main outstanding issues are the determination of the volume of intangible assets and the company's profit in a particular country, as well as the problems of double taxation.

Against this background, a debate is still ongoing amongst policy makers on the adoption of new tax measures at both the domestic and international level in order to adapt the 'brick and mortar' tax rules to the new digital landscape (Dimitropoulou, 2019).

The importance of the digital economy in the context of the OECD Action Plan on Base Erosion and Profit Shifting (hereinafter - the BEPS Action Plan ${ }^{1}$ ) is emphasized by the fact that the solution of the tax

1 OECD Action Plan on Base Erosion and Profit Shifting - OECD Publishing. Available at: http://dx.doi.org/10.1787/9789264202719-en [Accessed 05.05.2021]. 
problems of the digital economy is presented as the Action 1 of the BEPS Action Plan. ${ }^{2}$ In the era of the digital economy, new cost factors are coming to the fore, and physical distances are losing their relevance. In addition, digitalization increases the risks associated with base erosion and profit shifting and requires a review of a number of fundamental aspects of the international tax system, in particular the rules regarding where (the nexus concept) and how much (profit allocation) to tax.

The digital economy also raises broader tax challenges for policy makers. These challenges relate in particular to nexus, data, and characterization for direct tax purposes, which often overlap with each other. The digital economy also creates challenges for value added tax (VAT) collection, particularly where goods, services and intangibles are acquired by private consumers from suppliers abroad. ${ }^{3}$

Over the past few years, the Organization for Economic Cooperation and Development (hereinafter - the OECD), as well as the European Union (hereinafter - the EU) have made several attempts to find a solution to the tax problems of digitalization. However, so far, neither has succeeded in carving out proposals that would be acknowledged by a broad consensus (Geringer, 2020).

The relevant taxation options to address the challenges of the digital economy, discussed at the OECD, UN and EU levels, include broader and more radical tax policy considerations requiring a tax reform, ${ }^{4}$

2 OECD, (2015). Addressing the Tax Challenges of the Digital Economy, Action 1-2015 Final Report, OECD/G20 Base Erosion and Profit Shifting Project, OECD Publishing, Paris. Available at: http://dx.doi.org/10.1787/9789264241046-en [Accessed 05.05.2021].

3 OECD, (2015). Addressing the Tax Challenges of the Digital Economy, Action 1-2015 Final Report, OECD/G20 Base Erosion and Profit Shifting Project, OECD Publishing, Paris.

4 See Auerbach, A., Devereux, M.P., Keen, M. and Vella. J., (2017). DestinationBased Cash Flow Taxation, Oxford University Centre for Business Taxation, Working Paper 17/o1; Devereux, M.P. and Vella J., (2018). Debate: Implications of Digitalization for International Corporate Tax Reform. Intertax, 46(6/7), pp. 550-559. For some critical aspects of the proposed long-term solutions in the EU environment, see Björn, W., (2014). Taxation of the Digital Economy: An EU Perspective. Eur. Taxation, 54(12), pp. 541-544. 
as well as more refined, short-term solutions aimed at adjusting the current international tax system to the digital reality. ${ }^{5}$

\section{The OECD Concepts of Taxation in the Era of Digital Economy}

As noted in the OECD BEPS Action 1 Final Report, the digitalization of the economy has caused a number of complex problems in the field of direct taxation, mainly related to the issue of the distribution among States of the right to tax profits derived from cross-border activities in the digital era.$^{6}$ For example, when it comes to a new relationship based on digital presence, it is not only about countering the base erosion and profit shifting, but also about a new allocation of taxing rights.

It is possible to agree with Martín Jiménez who points out that BEPS Action 1 and all the ongoing work on digital economy seem to reveal a sort of tension between, on the one hand, the source rules identified as a consequence, especially of BEPS Actions 8-10 (income should be allocated to where value is added) and, in general, the BEPS Project outputs, and, on the other, the wishes of some countries and groups to include market states within the source rules in a form not directly contemplated by the BEPS Project outputs. This tension is at the heart of the unilateral solutions adopted by States, in parallel and after the BEPS works (Martín Jiménez, 2018).

On 16 March 2018, the OECD presented an interim report on tax challenges arising from digitalization (hereinafter - the Interim Report). ${ }^{7}$ The current work of the OECD on tax issues arising from the digitalization of the economy goes in two directions: pillar 1 and pillar 2.

Pillar 1 addresses the rules for the allocation of taxing rights, as well as the revised rules for the establishment of a tax reference (nexus), and namely:

- addresses the question of business presence and activities without physical presence;

5 For example, an interim tax which covers the main digital activities that currently escape tax altogether in the EU.

6 OECD BEPS Action 1 Final Report, p. 15.

7 OECD, Tax Challenges Arising from Digitalisation - Interim Report 2018. Available at: https://dx.doi.org/10.1787/9789264293083-en [Accessed 04.02.2021]. 
- will determine where tax should be paid and on what basis;

- will determine what portion of profits could or should be taxed in the jurisdictions where customers and/or users are located.

Pillar 2 represents global anti-base erosion mechanism:

- will help to stop the shifting of profits to low or no tax jurisdiction facilitated by new technologies;

- will ensure a minimum level of tax is paid by multinational enterprises (MNEs);

- will level the playing field between traditional and digital companies. $^{8}$

The solutions proposed so far include tax measures that indicate the jurisdiction of the source or destination. Relevant tax options for addressing the challenges of the digital economy, discussed at the OECD, UN and EU levels, also include short-term solutions aimed at adapting the existing international tax system to the digital reality ("quick fixes" or "interim measures") until a globally coordinated solution is reached.

\section{Proposals of the European Commission in the Area of Direct Taxation}

On March 21, 2018, the European Commission presented a digital tax package, which includes:

- Proposal for a Council Directive Laying Down Rules Relating to the Corporate Taxation of a Significant Digital Presence; 9

- Proposal for a Council Directive on the common system of a digital services tax on revenues resulting from the provision of certain digital services; ${ }^{10}$

8 OECD, Addressing the Tax Challenges of the Digitalisation of the Economy (2019). Available at: https: www.oecd.org/tax/beps/public-consultation-documentaddressing-the-tax-challenges-of-the-digitalisation-of-the-economy.pdf [Accessed 05.05.2021].

9 European Commission, Proposal for a Council Directive Laying Down Rules Relating to the Corporate Taxation of a Significant Digital Presence, COM (2018) 147 final (21 Mar. 2018).

1o European Commission, Proposal for a Council Directive on the common system of a digital services tax on revenues resulting from the provision of certain digital services, COM (2018) 148 final (21 Mar. 2018). 
- Communication from the Commission to the European Parliament and the Council - Time to establish a modern, fair and efficient taxation standard for the digital economy. ${ }^{11}$

The main task at the EU level is to prevent the fragmentation of the internal market and to establish new rules that would bring the taxation of profits in line with the standard of value creation. According to the EU proposals, this will be achieved mainly by taking into account the cost created by users of digital services when they interact with the digital interface through which they receive the taxable service.

\section{The EU DST Concept}

Let us consider the EU proposal on the common system of taxation of digital services in the EU (digital services tax, hereinafter - DST) and its assessment in accordance with the primary EU law. The preferred interim solution to the task of reconciling taxation with value creation in the EU is to introduce a $3 \%$ tax on the income generated for certain companies from the provision of specific digital services (Article 8 of the DST proposal). The subject of regulation is limited to the taxation of services for which the user's contribution to value creation is significant. According to Article 3 of the DST proposal, the contribution of users is considered significant in the following categories of services:

- the placing on a digital interface of advertising targeted at users of that interface;

- the making available to users of a multi-sided digital interface which allows users to find other users and to interact with them, and which may also facilitate the provision of underlying supplies of goods or services directly between users;

- the transmission of data collected about users and generated from users' activities on digital interfaces (Article 3 of the DST proposal). From the above list, it follows that the services that fall under the DST:

- are aimed at the participation of users in the provision of services;

${ }^{11}$ European Commission, Communication from the Commission to the European Parliament and the Council - Time to establish a modern, fair and efficient taxation standard for the digital economy, COM (2018) 148 final (21 Mar. 2018). 
- represent intermediary services provided through a digital platform.

Every service that is not associated with a significant user participation in the provision of this service is beyond the scope of taxation. In particular, the provision of digital content through a digital interface is not subject to the tax, while the provision of a multi-user interface through which users can download and share digital content is within the scope of the tax, since the latter rather consists of user-generated content (explanatory note to the DST proposal).

In addition, according to Article 4 of the DST proposal, a company will qualify as a taxable person for DST purposes only if:

- the total amount of global income for the last full financial year for which financial statements are available exceeds EUR 750,000,000; and

- the total amount of taxable income received in the EU during this financial year exceeds EUR 50,000,000.

Limiting the use of DST only to companies that meet these thresholds (in combination with taxable activities) is explained by the Commission by the fact that these levels of selected turnover thresholds reflect the large economic potential of these enterprises, which in turn indicates the ability to attract a large number of users to whom these enterprises prefer to carry out their activities.

Article 5 of the Proposal for a DST Directive determines the place of taxation of the revenues generated from the above taxable services and thus, allocate the taxing rights to the Member State where the user of the services is located. The location of the user is determined for each service received and is deemed to be the place indicated by the IP address of the user or the place indicated by any geolocation method. The place from where the payment for the receipt of the service is made is irrelevant for the nexus determination under the DST. The EU Member States debated the proposal at length, including considering various amendments. However, no further solutions have been made since then. 


\section{Unilateral Measures to Introduce DST}

The discussion on the digital tax at the EU level has not progressed since the beginning of 2021 due to the pandemic, so in 2020 the French Government announced the introduction of a DST at a rate of $3 \%$, regardless of the presence or absence of international agreements. The French DST has been named the "GAFA tax" (by Google, Apple, Facebook and Amazon). However, despite the fact that most of the digital giants are obviously American companies, the GAFA tax targets not only American groups, but also other international groups, including French, Chinese, German, Spanish, and English groups.

The DST Law $^{12}$ applies to the relationships it regulates from January 1, 2019. In 2020, DST was also introduced in Austria,,$^{13}$ the United Kingdom, ${ }^{14}$ Hungary, ${ }^{15}$ Italy ${ }^{16}$ and Turkey. ${ }^{17}$ The specifics of the DST vary from country to country. In Austria and Hungary, the digital tax applies only to online advertising services. In France, the scope of the tax is broader: it covers the digital interface and advertising services. The tax rate varies from $3 \%$ in France to $7.5 \%$ in Hungary and Turkey.

12 Bill No 2019-759 dated July 24th, 2019 on the creation of a tax on digital services (1). Available at: https://www.impots.gouv.fr/portail/files/media/1 metier/5_international/french_dst_en_v2.pdf.

13 Digitalsteuergesetz 2020 (DiStG 2020). StF: BGBl. I Nr. 91/2019 (NR: GP XXVI IA 983/A AB 686 S. 88. BR: AB 10251 S. 897.) [CELEX-Nr.: 32011Loo16, 32018Lo822].

14 Finance Act 2020 // https://www.legislation.gov.uk/ukpga/2020/14/ contents/enacted.

15 Act XXII of 2014 on Advertisement Tax [AT Act], as amended by the Act XLVII of 2017 [Modification Act].

16 LEGGE 30 dicembre 2018, n. 145 Bilancio di previsione dello Stato per l'anno finanziario 2019 e bilancio pluriennale per il triennio 2019-2021. (18Goo172). (GU n.302 del 31-12-2018. Suppl. Ordinario n 62).

17 The Law No 7194 on Digital Service Tax and the Amendment of Certain Laws and Law Decree No 375. Official Gazette, 07.12.2019, Nr. 30971. 


\section{V.1. General Characteristics of the French Digital Services Tax}

Taxpayers are defined as French and foreign companies for which the annual income from taxable services exceeds both thresholds, namely 750 million euros of global income and 25 million euros received in France.

The DST applies to gross revenue collected in return for providing taxable service over the course of a calendar year in France. ${ }^{18}$

The tax is levied on two types of digital services provided in France providing a digital interface that allows one user to interact with others (intermediary services). The French Tax Authority has issued draft guidance on the scope and calculation of DST and related compliance issues. According to the document, the first category of digital mediation services includes digital interfaces that allow users to make transactions between them (delivery of goods or services), for example, Amazon or Alibaba. The second category includes network services that allow users to interact with each other without being able to make transactions through the digital interface itself. Examples of such services are social networks and online games.

However, this definition excludes certain services, such as when a company operating through a website sells the user goods or services that it owns. For example, Amazon, which sells books to a user from its own warehouse, will not fall within the scope of the digital tax. In contrast, if a company sells books using Amazon, such an Amazon service will be covered by DST, as it acts as an intermediary providing advertisers with services aimed at placing targeted advertising messages on a digital interface based on data collected about users and formed in agreement with such an interface. Advertising services on the digital interface that are not focused on user data are exempt from the tax.

The services of the digital platform are linked to the location of users. If one of the users of the platform is located in France during the tax year, the service will be considered provided in France. The user's location is determined by the IP address.

18 Bill No 2019-759 dated July 24th, 2019 on the creation of a tax on digital services (1). 
The GAFA tax does not apply to platforms for which the collection of user data is not the primary purpose:

- digital content (e-commerce, video or music on demand);

- communication services;

- payment services.

Thus, the tax base will depend on how much of the payments are related to France, the type of services and the type of platform. The reporting rules and the tax compliance system are established by analogy with VAT. The company or the responsible member of the group pays the tax in two parts: in April and in October. When calculating the income covered by the digital tax, companies can exclude the amounts of covered income that went to pay VAT.

The statute of limitations for DST is six years. The digital services tax will be deducted from the French corporate income tax base. In addition, it is possible to form a consolidated group of DST taxpayers. One company must be designated as a responsible taxpayer on behalf of all the companies in the group.

\section{V.2. Comparison of the French DST and the European Commission's Proposals}

The EU proposal imposes a $3 \%$ tax on income earned by companies from providing three categories of services in the EU. According to Article 3 of the EU proposal, taxable services are:

a) user-oriented online advertising;

b) a digital interface that allows users to find other users and interact with them;

c) transfer of data collected about users and obtained as a result of user activities through digital interfaces.

Unlike the EU proposal, the French DST focuses only on two services: intermediary services and targeted advertising. On the other hand, the EU project excluded digital interfaces for content delivery, unlike the French DST.

The EU proposal excluded digital interfaces for content delivery, unlike the French DST. Based on paragraph 15 of the EU proposal, digital content should be defined as data provided in digital form, 
such as computer programs, applications, games, music, videos or texts, regardless of whether they are available through download or streaming, with the exception of data provided by the digital interface itself. French officials said the Apple App Store would be covered by the DST, meaning the French tax would not exclude apps as excluded by the EU proposal.

The income thresholds proposed by the European Commission and France also differ. According to the draft EU directive, an organization is subject to tax only if the total amount of global income exceeds 750 million euros, and the total amount of taxable income received by the organization within the EU exceeds 50 million euros. The French thresholds are 750 million euros, and 25 million euros in France. The main difference is that the EU calculates the threshold of global revenue from the total revenue of the company, and not only from the services covered by the tax, as in France. Therefore, many multinational companies will not be covered by the French DST. The global income threshold under the French DST excludes many successful French companies that provide taxable services only as part of their business (for example, Carrefour, which operates through its online store, among other things). ${ }^{19}$

\section{DST and Double Taxation Issues}

It is widely believed that DST is contrary to the principle of avoiding double taxation, since the tax is applied to revenue, not income. The OECD Model Convention on Taxes on Income and Capital (hereinafter referred to as the OECD $\mathrm{Model}^{20}$ ) applies to taxes on income and capital levied on behalf of a Contracting State. In this regard, it is important to talk about the legal nature of DST, which is close to turnover taxes.

The DST was designed that way as not to fall within the DTTs scope. But the goal of avoiding double taxation is to ensure that the

19 Report on France's Digital Service Tax Prepared in the Investigation under Section 301 of the Trade Act of 1974, (2019).

${ }_{20}$ Model Tax Convention on Income and on Capital: Condensed Version, (2017). OECD Publishing. Available at: https://doi.org/10.1787/mtc_cond-2017-en [Accessed 23.04.2021]. 
same income is not taxed twice. However, taking into account corporate taxation, the picture is likely to be as follows. First, the profit will be taxed in France as income under the digital tax, and second, as income under the corporate income tax of the country where the company pays its corporate income tax. The reason for this is that the country in which the company is resident will not exclude DST-related income from its base or provide a deduction for any amount paid.

Besides, it should be noted that the French DST was designed to tax the largest digital companies, mainly American ones. Therefore, there are many questions about discrimination and the inconsistency of the French law with international tax principles.

\section{Relevance of the French Experience for Russia}

The experience of foreign countries shows that there is a trend of introducing national digital taxes, but these taxes have many differences from each other, which leads to double taxation, lack of legal certainty and distortion of competition. In addition, the experience of France shows the risk of international tension with the unilateral introduction of a digital tax.

On the other hand, the provisions of the Tax Code of the Russian Federation on VAT and income tax do not allow to fully collect taxes on income of corporate groups that use digital business models when providing services related to Russian users. At the same time, Russian organizations that conduct similar activities face full tax burden, which allows us to conclude that Russian companies are discriminated against foreign ones.

Russian companies bear a large tax burden and cannot provide a competitive financial offer to content producers and service providers, so it is more cost-effective for them to work with foreign platforms. At the same time, Russian companies are required to withhold personal income tax when making income payments to individuals who are tax residents of the Russian Federation.

Foreign companies are not personal income tax agents, they do not pay insurance premiums when paying remuneration to individuals, and apply the income tax rates provided by the countries of their 
incorporation. At the same time, their profits are generated at the expense of the user base located in Russia.

In addition, Russian companies that provide digital services to users in other countries may find themselves in a situation where their income will be charged a digital tax in these countries, which will lead to double taxation of the income of Russian companies from such operations.In this regard, it is advisable to consider the issue of taxation in Russia of the part of the profits extracted by foreign companies in the Russian market.

In 2020, the course of reforms was affected by the crisis caused by the COVID-19 pandemic. It remains unclear whether countries will move towards a multilateral approach or unilateral measures. The current situation, where citizens are increasingly using digital services for remote work and leisure due to self-isolation and quarantine, underlines the relevance of the OECD/G20 digital taxation project. Governments are mobilizing their tax systems to deal with the economic crisis, putting pressure on national budgets. This could create a dilemma for governments in the negotiations to tax digital companies, many of which will make super-profits in 2020: states will not be able to arbitrarily raise national taxes (which will almost certainly be the result of any G20/OECD agreement) during or after the economic crisis.

The experience of foreign countries shows that there is a trend of countries adopting their own digital taxes, but these taxes have many differences from each other, which leads to double taxation, reduced transparency and certainty for business, as well as distortion of competition. In addition, the experience of France and the Czech Republic shows the risk of international tension with the unilateral introduction of a digital tax.

Some countries (France, Italy) levy a tax of $2-3 \%$ on the total income of MNEs from a similar list of services (online advertising, online mediation, sale of user-generated data) related to individuals and legal entities located on their territory, with similar methods of determining the location of users. At the same time, there is a desire to take into account the basic ideas of the OECD (focus on companies that remotely communicate with their users, for which an important 
element of business is working with data and marketing, the presence of significant revenue thresholds for applying a digital tax).

The countries of the second group (India and Hungary) levy a tax of 5-7 \% on income from the provision of advertising services, while establishing a different list of specific taxable services, tax agents, etc. The only thing that Indian and Hungarian taxes have in common is that they are charged conceptually from advertising services. The experience of this group of countries cannot be considered successful.

The existing Russian tax legislation on VAT and income tax does not allow Russia to fully collect taxes on the income of digital MNEs that provide services to Russian users. We believe that the need to prepare responses to the challenges of the digital economy in the new conditions at the level of Russian legislation is beyond doubt. The specific feature of Russia is that it is both a market-consumer of digital services and a provider of such services, having internationally competitive IT companies: Yandex, VKontakte, Wildberries, etc. However, Russian tax legislation has a number of features that allow foreign Internet companies to gain tax advantages in relation to Russian Internet companies.

Foreign companies are not tax agents for personal income tax (hereinafter referred to as personal income tax), they do not pay insurance premiums when paying remuneration to individuals, and apply the income tax rates provided for by the countries of their incorporation. Accordingly, Russian technology companies bear a large tax burden and cannot provide a competitive financial offer to content producers and service providers who are more economically profitable to work with foreign platforms.

In this regard, we consider it appropriate to consider the issue of assigning foreign digital companies (in particular, Facebook, Twitter, Apple) the functions of tax agents when paying income to individuals for services rendered by them.

We believe that the key challenges of regulating the taxation of digital companies in the Russian Federation are:

- protection of competition; 
- ensuring equal conditions for all market participants, regardless of the origin of capital and the underlying jurisdiction; the

- presence of clear criteria for determining the range of regulated entities;

- effective enforcement mechanisms in place;

- introduction of a tax regime that encourages the development of the Russian market and national digital companies.

\section{Conclusion}

The meaning of the digital economy is growing day after day. The digitalization brings the whole world on the new level leading to the overall well-being. In 2020 digitalization helped businesses and the whole society to survive and to continue surviving the COVID-19 times. The development of the digital economy brings a lot of benefits, but at the same time gives rise to tax challenges. The issue relates to the question of how taxing rights on income generated by the digital companies from cross-border activities should be allocated among countries. The main characteristics of the digital economy from the point of view of taxation are the reduction of the need for physical presence in the markets, as well as a new model for creating value through user interaction.

The appearance of new business models makes it possible for companies to provide services to customers around the world and gain revenue without any physical presence in the countries and therefore, not allowing to establish the sufficient connection with country in order to have taxing rights over non-resident company.

Countries realize that the existing tax legislation can't ensure that profits of the digital companies are taxed where the actual economic activity generating the profit are performed and where the value is created. Thus, countries cannot get their fair share of the tax revenues pie from the non-resident digital companies, that are gaining big part of their profits in the jurisdiction of the countries.

Moreover, governments and society express growing concern about tax planning by massive multinationals that make use of the gaps in the existing tax legislation in order to reduce taxable income or shift profits 
to low-tax jurisdictions. As a result, the rise of the digital economy derived the need to adapt existing tax systems and rules. The issue of taxation of digital multinational companies is on international agenda for a long time. Several attempts were made by the OECD, as well as by the EU in order to tackle the problem concerning the taxation of the digital businesses, but no coordinated solutions have been found yet.

As far as can be ascertained, the OECD and the European Union are pulling in the same direction, although it seems that the Commission has taken a decisive step forward in this respect. It remains to be seen whether these proposals will be successful. However, uncoordinated and unilateral interim measures, which have the same aims and measures of implementation, may be a disincentive for countries to pursue longer-term multilateral solutions. Nevertheless, issues of overcoming unilateralism should be identified by the international community (Ponomareva, 2019).

In response to the deadlock at the OECD and EU levels, some countries moved forward with introduction of uniliteral measures regarding the issue of a fair taxation of the digital economy (Geringer, 2020). France was one of the first countries that enacted the digital services tax.

According to the EU proposal, one of the characteristics of the DST is that it will not be subject to domestic or foreign corporate tax and applies without discrimination to domestic and cross-border services, on the one hand, and to domestic and foreign taxpayers, on the other. France, by contrast, allows businesses to deduct DST paid as an expense from the corporate income tax base, and therefore puts French companies in a better position. This will not discriminate only if DST is implemented by countries around the world.

It is currently problematic to equate international tax coordination with the traditional income tax treaty framework. That is why some countries have started to apply unilateral measures. The implementation of national digital tax is accompanied by many side-effects (Geringer, 2020). It will take long time to find a unified solution. Countries should be careful with designing and implementing new tax policies. 


\section{References}

1. Auerbach, A., Devereux, M.P., Keen, M. and Vella, J., (2017). Destination-Based Cash Flow Taxation. Oxford University Centre for Business Taxation, Working Paper, 17/01.

2. Björn, W., (2014). Taxation of the Digital Economy: An EU Perspective. European Taxation, 54(12), pp. 541-544.

3. Devereux, M.P. and Vella, J., (2018). Debate: Implications of Digitalization for International Corporate Tax Reform. Intertax, 46(6/7), pp. 550-559.

4. Dimitropoulou, C., (2019). The Digital Services Tax and Fundamental Freedoms: Appraisal Under the Doctrine of Measures Having Equivalent Effect to Quantitative Restrictions. Intertax, 47(2), pp. 201-218.

5. Geringer, S., (2020). National Digital Taxes-Lessons from Europe. South African Journal of Accounting Research, 35(1), pp. 1-19, doi: 10.1080/10291954.2020.1727083.

6. Martín Jiménez, A., (2018). BEPS, the Digital(ized) Economy and the Taxation of Services and Royalties. Intertax, 46(8/9), pp. 620-638.

7. Ponomareva, K., (2019). Comparison of Proposals to Adjust the Permanent Establishment Concept to the Digital Economy. Bulletin of International Taxation, 73(11), pp. 581-589.

\section{Information about the author}

Karina A. Ponomareva, Cand. Sci. (Law), Associate Professor, Department for State and Municipal Law, Dostoevsky Omsk State University

50 Let Profsoyuzov St., 100/1, Omsk 644077, Russia

karinaponomareva@gmail.com 